\title{
TRUANCY PROSECUTIONS OF STUDENTS AND THE RIGHT [TO] EDUCATION
}

\author{
DEAN HILL RIVKIN†
}

The situation is truly ironic. The argument for retaining beyond-control and truancy jurisdiction is that juvenile courts have to act in such cases because "if we don't act, no one else will." I submit that precisely opposite is the case: because you act, no one else does. Schools and public agencies refer their problem cases to you because you have jurisdiction, because you exercise it, and because you hold out promises that you can provide solutions. ${ }^{1}$

- Judge David Bazelon

INTRODUCTION: GOING TO SCHOOL ON TRUANCY

I.TRUANCY, SCHOOLS, AND THE COURTS

II. ThE NONTRANSPARENT LEGAL CONTOURS OF TRUANCY .................................. 146

A. The Right to Counsel in Truancy Cases .............................................. 148

B. Guilty Pleas in Truancy Prosecutions ................................................ 149

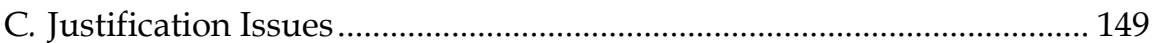

D. Valid Court Orders and Orders of Probation......................................... 151

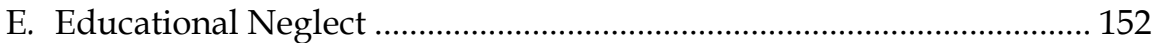

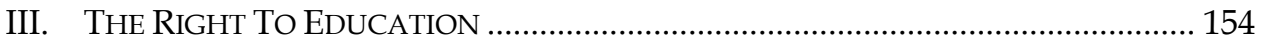

IV. THE Right TO THE Right EdUCATION........................................................... 158

$\dagger$ Dean Hill Rivkin is a College of Law Distinguished Professor at the University of Tennessee College of Law. This article grew out of the legal work of a course that I taught during the 2009-10 academic year called Public Interest Lawyering: Education Law Practicum. I am deeply indebted to the students and the two supervising attorneys in this course, Barbara Dyer and Brenda McGee, for their unwavering commitment to improving the educational lives of the at-risk children and for their thoughtful development of strategies designed to reform the truancy system. Eliot Kerner, my research assistant, was indispensable in the production of this piece.

1. Gordon Bazemore, Leslie A. Leip \& Jeanne Stinchcomb, Boundary Changes and the Nexus Between Formal and Informal Social Control: Truancy Intervention as a Case Study in Criminal Justice Expansionism, 18 Notre DAME J.L. ETHICS \& PUB. POL'y 521, 527 (2004) (quoting David Bazelon, Jurisdiction over Status Offenses Should be Removed from the Juvenile Court, 21 CRIME \& DELINQ. 97, 98 (1975)). But see, Lawrence H. Martin \& Phyllis R. Snyder, Jurisdiction over Status Offenses Should Not Be Removed from the Juvenile Court, 22 CRIME \& DELINQ. 44 (1976) (arguing against removal of status offenses because families "under stress would receive fewer services"). My thinking on this subject benefited from the nuanced discussion of the criminalization of truancy by criminologists Bazemore, Leip, and Stinchcomb's 2004 article above. 
A. The Special Education Model ................................................................... 158

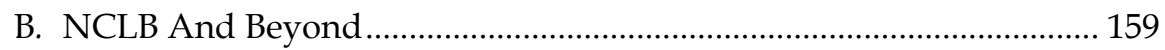

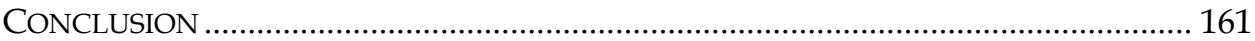

\section{INTRODUCTION: GOING TO SCHOOL ON TRUANCY}

Since the inception of universal compulsory education, ${ }^{2}$ the issue of truancy has defied easy solution. At the center of the current ferment in public education in the United States, the tangled roots of truancy are a microcosm of the myriad problems afflicting our nation's schools. The complex causes of truancy have been chronicled in the social science and education literature. Many pilot projects and practices have been launched to reduce the sizeable numbers of students who fail to attend school. ${ }^{3}$ Though some intervention efforts have succeeded in reducing truancy rates, the overall success of these projects is in serious doubt. Judging from the continuing attention to truancy issues by school systems, law enforcement authorities, juvenile courts, legislative bodies, and others, the tenacious problem of truancy continues to plague school systems nationwide. ${ }^{4}$

In the extensive literature on truancy reduction, no firm consensus exists on model, evidence-based, replicable programs. ${ }^{5}$ There have been a plethora of experimental initiatives designed to develop best practices for addressing truancy, ${ }^{6}$ but only a few of these programs have been subjected to rigorous examination. Despite the dearth of data demonstrating the problems created by using prosecutions as a vehicle for improving school attendance and stemming truancy, there is continued reliance on the prosecution of students and parents

2. There is vast literature on the history and purposes of compulsory education. See, e.g., PAT CARlen, Denis GleEson \& Julia WARdhaugh, TRuANCY: THE POlitics OF COMPUlsory SCHOOLING (1992). One prominent educator cites protection of children from "economic serfdom" as the only valid justification for compulsory attendance laws. Dennis Doyle, Foreword to RITA E. GUARE \& BRUCE S. COOPER, TRUANCY REVISITED: STUDENTS AS CONSUMERS xii (2003).

3. See, e.g., Kern COUnty Truancy Reduction Program (Aug. 16, 2010), http:// kcsos.kern.org/schcom/trp; CENTER FOR CHILDREN's ADVOCACY, TRUANCY COURT PREVENTION PROJECT (2007), http://www.kidscounsel.org/aboutus_programs_tcpp.htm; THE STOP TRUANCY AND RECOMMENDED TREATMENT (S.T.A.R.T.) PROJECT (2011), http://courts.phila.gov/courterly/ summer/start.htm; CHILDREN IN NEED OF SERVICES (BEECA) (2011), http://www.kingcounty.gov/ courts/JuvenileCourt/becca.aspx.

4. See, e.g., Brent Begin, Truants Threatened with Legal Action, S.F. EXAMINER, Aug. 13, 2010, available at http://www.sfexaminer.com/local/truants-threatened-legal-action; Charlotte Sanders, New Law on Excessive School Absences, Williamson Daily NeWs, Aug. 12, 2010, at 1A; James Haug, Troubled Teens Might Lose Wheels Under Schools Plan, LAS VEgAS REV.-J., Aug. 5, 2010, at 1A; Erin Sherbert, City Officials Ramp Up Efforts to Curb Truancy at Problem Campuses, S.F. ExAMINER, Aug. 3, 2010, available at http://www.sfexaminer.com/local/city-officials-ramp-efforts-curb-truancyproblem-campuses.

5. See MYriam L. BAKER, ET AL., U.S. DeP'T OF Justice, TRUANCY REDUCTION: KEEPING StUdENTS IN SCHOOL 6-7 (2001), available at http:/ / www. ncjrs.gov/pdffiles1/ojjdp/188947.pdf (explaining the inadequacies of the example programs).

6. See, e.g., LynN BYe, Michelle E. Alvarez, JANET Haynes \& Cindy E. SWeigart, Truancy PREVENTION AND INTERVENTION: A PRACTICAL GUIDE 61-109 (2010); KEN REID, TRUANCY AND ScHoOls 102-218 (1999); Melissa K. Hunt \& Derek R. Hopko, Predicting High School Truancy Among Students in the Appalachian South, 30 J. OF PRIMARY PREVENTION 549, 550 (2009). 
for truancy offenses. ${ }^{7}$ Overall petitioned truancy cases increased by $92 \%$ between 1987 and 1996, including a 97\% increase among black students, 70\% among white students, and $11 \%$ for students of other groups. ${ }^{8}$ Prosecuting students for truancy often generates harmful direct and collateral consequences: incarceration, ${ }^{9}$ fines, involuntary community service, recursive court involvement, ${ }^{10}$ loss of driving privileges, imposition of curfews, specification of conditions of probation that require students to meet unrealistic school performance standards, unwarranted disclosures of personal information, investigations of family dependency and neglect, mental health consequences, ${ }^{11}$ monitoring students through radio frequency identification technology (RFID), ${ }^{12}$ grade reductions, ${ }^{13}$ and others. ${ }^{14}$

The rule of law - the expectation that, even in juvenile courts, fair procedure and adherence to constitutional norms is essential-is often abused in truancy prosecutions. As recounted in the complaint in a recent class action filed in Rhode Island challenging the practices in truancy courts:

In violation of federal and state law, these children are deprived of, among other things, adequate notice of what conduct will result in commencement of truancy proceedings or in punishment for being "truant"; adequate and timely notice of the charges against them; a preliminary investigation of those charges by the Family Court's intake office to determine legal sufficiency and propriety of the

7. See, e.g., BYE ET AL., supra note 6, at 19-26 (surveying state truancy laws); GuARE \& COOPER, supra note 2, at 76-77 (describing the "law-and-order" approach in Tulsa County, Oklahoma); Karl F. Dean, Criminalization of Truancy, 34 NEW ENG. L. REV. 589 (1999) (decrying the trend toward incarceration of students for truancy). In Texas, between 2005 and 2009 the number of "failure to attend school" charges filed by schools increased more than $40 \%$ from about 85,000 to 120,000. Forrest Wilder, School House Crock: Why Is Texas Prosecuting Adults For Dropping Out, TeXAS ObSERver, Apr. 1, 2010, available at http://www.texasobserver.org/cover-story/school-house-rock. In Denver, Colorado, there were 1,600 open truancy cases in October, 2010. Jeremy P. Meyer, Denver Truancy Court's Careful Help Leads Kids Back To Classrooms, DENVER Post, Oct. 25, 2010, at A-01.

8. JAY SMINK \& JOANNA ZORN HEILbRUNN, ClEMSON UniV., NAT'L Dropout PREvention CENTER, LEGAL AND ECONOMIC IMPLICATIONS OF TRUANCY 21 (2005). Despite diligent efforts to locate more recent national statistics on truancy prosecutions, no credible data have been found in compilations of either education or juvenile justice statistics maintained by the United States Department of Education or the United States Department of Justice.

9. The one study on the efficacy of incarceration as a remedy for halting truant behavior concluded that it did not have a material effect on subsequent school attendance. JOANNA ZORN HEILBRUNN, NAT'L CENTER FOR SCH. ENGAGEMENT, JUVENILE DETENTION FOR COLORADO TRUANTS: EXPLORING THE ISSUES 20-28 (2004). The legality of escalating "unruly" truancy petitions into delinquency charges for a student's violation of an order of probation was questioned in one state. Compulsory School Attendance and Truancy Statutes, Op. Tenn. Att'y Gen. 08-27 (Feb. 15, 2008).

10. A study has shown that a first-time court appearance during high school increases a student's chances of dropping out of high school. Gary Sweeten, Who Will Graduate? Disruption of High School Education by Arrest and Court Involvement, 23 JUSTICE Q. 462 (2006).

11. See Jack Daniel, Amy Tillery \& Denise Whitehead, Fresno's Juvenile Behavioral Health Court: A Better Way to Serve Youth, 43 Clearinghouse ReV. J. OF POVERTY L. \& POL'Y 43 (2009) (describing a multidisciplinary, collaborative approach to generating better outcomes for court-involved youth with mental health problems).

12. See Patrick Sills, Reasons Why Schools Should Not Track Students With RFID Chips, HELIUM, http:/ / www.helium.com/items/1934092-reasons-why-schools-should-not-track-students-with-rfidchips (Aug. 26, 2010) (describing a New Canaan, Connecticut proposal).

13. See Knight v. Bd. of Educ. of Tri-Point Cmty. Unit Sch. Dist. No. 6J, 348 N.E.2d 299 (Ill. App. 1976).

14. BYE ET AL., supra note 6, at 19-26. 
charges; the right to consult with an attorney and to have one appointed for them if they cannot afford one; an adequate explanation of their rights to remain silent, to confront school officials and to require school officials to prove the charges beyond a reasonable doubt; an opportunity to rebut the charges against them if they believe that they have been falsely accused; transcripts of Truancy Court proceedings so they that have a record of statements made to and by them; interpreters if they do not speak or have difficulty speaking English; and, if the children admit to the charges against them and agree to abide by the terms and conditions of the Truancy Court, the right to challenge school officials who claim that they have violated those terms and conditions. In addition, their parents and guardians are subjected to punitive orders of the Truancy Court despite the fact that they are not parties to the proceedings against their children. ${ }^{15}$

In 2007, there were 57,000 truancy petitions filed in juvenile courts nationwide. ${ }^{16}$ This represented a 67 percent increase from petitions filed in 1995. ${ }^{17}$ Forty-five states invoke the jurisdiction of juvenile and family courts in truancy cases. ${ }^{18}$ Thirty-nine states address truancy as a status offense. ${ }^{19}$ Thirtythree states provide the right to counsel at all stages of truancy proceedings. ${ }^{20}$ Few practice guides exist for the desultory number of lawyers who defend students in truancy cases. ${ }^{21}$ Despite the potential consequences of truancy prosecution, truancy defense is a veritable backwater, with relatively few reported cases. The justifications for continuing to prosecute students for truancy are contrary to the general goals of state-sanctioned crime and punishment and to the ostensibly rehabilitative purpose of the juvenile court.

15. Class Action Complaint at 4, Boyer v. Jeremiah, No. 2010-2858 (R.I. Super. Ct. Mar. 29, 2010). See also Class Action Complaint, De Luna v. Hidalgo County, No. 7:10-cv-00268 (S.D. Tex. Jul. 26, 2010) (challenging the practice of jailing youth seventeen and older in an adult detention center, often for periods up to several months, because of their inability to pay fines and costs associated with missing school).

16. Laura Fear \& Catherine Krebs, Counting All Children: ABA Conference Focuses on Truancy, AMERICAN BAR ASSOICATION (Nov. 12, 2010), http://apps.americanbar.org/litigation/committees/ childrights/content/articles/111210-truancy.html (citing BENJAMIN ADAMS, CHARLES PUZZANCHERA, \& MELISSA SICKMUND, Nat'l Ctr. for Juvenile Justice, JUvENILE COURT STATISTICS 2006-2007 (2010), available at www.ncjjservehttp.org/ncjjwebsite/pdf/jcsreports/jcs2007.pdf).

17. Id.

18. Brief for Juvenile Law Center as Amici Curiae Supporting Respondent at 3, Bellevue School Dist. v. E.S., No. 83024-0, (Wash. filed Dec. 18, 2009).

19. Id. at 6 .

20. Id. at 3. See generally Katherine Hunt Federle, Lawyering In Juvenile Court: Lessons From a Civil Gideon Experiment, 37 FORD. URB. L.J. 93, 107-08 (2010) (discussing the right to counsel in status offense cases). A precedent-setting constitutional challenge asserting the right to counsel at the initial truancy hearing was upheld in Bellevue Sch. Dist. v. E.S., 199 P.3d 1010, 1017 (Wash. Ct. App. 2009). See discussion infra Part III.

21. Benton et Al., A.B.A. Center on Children \& THE LAW, Representing Juvenile StAtus OFFENDERS vii (2010), available at http://www.americanbar.org/content/dam/aba/migrated/ child/PublicDocuments/RJSO_FINAL.authcheckdam.pdf ("There are few training resources for attorneys representing juvenile status offenders or youth who are truant, runaways, or beyond their parent's control."). An exception is the excellent manual published by Team Child and the ACLU of Washington. TEAM CHILD, ACLU OF WASHINGTON, DEFENDING YOUTH IN TRUANCY PROCEEDINGS: A PRACTICE MANUAL FOR ATTORNEYS (2009), available at http://www.teamchild.org/pdf/ Truancy\%20Manual\%20FINAL\%20(rev.10.09).pdf. 
This article has a focused ambition. It will not canvass or evaluate the plentiful social science literature on truancy and truancy reduction programs. ${ }^{22} \mathrm{It}$ will be centered on the prosecution of students for truancy, not parents. ${ }^{23}$ Section II analyzes the institutional forces at play in truancy prosecutions of students. With an emphasis on the role of school systems, the section examines the incentives and disincentives that motivate the multiple players involved in these prosecutions. Section III identifies salient legal issues that arise in truancy prosecutions of students. These issues often occupy a low-visibility corner of the juvenile justice system despite their significant impact on juvenile defendants.

Section IV examines the "right to education" line of cases. This mix of cases blends federal and state constitutional and statutory rights to create a right to adequate, student-specific, comprehensive educational and social service interventions designed to address issues of truancy. This right has been termed "the right to learn."24 This right draws on due process, equal protection, the state right to education articulated in the school finance and school adequacy cases, the "No Child Left Behind" legislation, ${ }^{25}$ and state laws that require exhaustion of a variety of steps by school systems prior to the filing of a truancy petition against a student, ${ }^{26}$ and, in some states, a showing by the school system or the prosecuting authorities that a student's absences were not justified. ${ }^{27}$ Combined, these sources of law yield a defense or remedy for each student before prosecution.

Section V explains the structure of this right. It is modeled on the remarkable array of approaches to educating students with disabilities under the IDEA ${ }^{28}$ and section 504 of the Rehabilitation Act. ${ }^{29}$ These schemes require school systems to develop comprehensive plans for individual student's educational progress. This article argues that such an approach must be fully exhausted before school systems are permitted to file truancy petitions against students. The conclusion advocates the decriminalization of truancy for students and

22. See generally BYE ET AL., supra note 6; GUARE \& COOPER, supra note 2; REID, supra note 6. For an example of a truancy reduction program that is making progress in its efforts, see Barbara A. Babb \& Gloria Danziger, Addressing Truancy is a Complex Challenge, BALTIMORE SUN, Jul. 30, 2010, available at http:/ / articles.baltimoresun.com/2010-07-30/news/bs-ed-truancy-letter-20100730_1_truancy-courtprogram-truant-law-students. See also Charles Edward Pell, Pre-offense Monitoring of Potential Juvenile Offenders: An Examination of the Los Angeles County Probation Department's Novel Solution to the Interrelated Problems of Truancy and (Juvenile) Crime, 73 S. CAL. L. REV. 879 (2000).

23. See infra Part III.E (discussing educational neglect). See also Gilbert Bradshaw, Must Utah Imprison its Parents and Children?: Alternatives to Utah's Compulsory Attendance Laws, 22 BYU J. PUB. L. 229 (2007).

24. Note, A Right to Learn?: Improving Educational Outcomes Through Substantive Due Process, 120 HARV. L. REV. 1323 (2007).

25. 20 U.S.C. $\S \S 6301-6578$ (2006).

26. For an analysis of the diversity in State approaches to providing status offenders with services see JessiCA R. KENDALL, A.B.A. CTR. ON CHILDREN \& THE LAW, FAMILIES IN NEED Of CRITICAL Assistance: Legislation AND POlicy Aiding Youth WHO ENGAGE IN NONCRIMINAL MisbeHAVIOR (2007).

27. See, e.g., TENN. CODE ANN. § 37-1-102(b)(25)(A)(i) (2011). Bullying is an example of a justification for school absences that has only recently gained more prominent attention. See Billie Gastic, School Truancy and the Disciplinary Problems of Bullying Victims, 60 EDUC. REV. 391 (2008).

28. 20 U.S.C. $\S \S 1400-1491$ (2006).

29. 29 U.S.C. § 794 (2006). 
sketches a vision for education reform that will reduce the unacceptable number of students who are chronically absent from school and often drop-out or are pushed out from formal education. This will allow each student a meaningful opportunity, however unconventional, to succeed in the transition to adulthood.

\section{TRUANCY, SCHOOLS, AND THE COURTS}

For several years I have suspected that our schools condition some criminalsthat for many school-age children, present educational practices backfire in their social intent. But I couldn't put my finger on the how and why of it until I visited a children's court recently. ${ }^{30}$

- Arthur C. Johnson, Jr. (1942)

Educational law scholarship has explored the multiple causes of truancy, including societal influences, cultural norms, psychological pressures, and educational inadequacies. ${ }^{31}$ Tackling these root causes student-by-student using a multi-systemic approach is demanding work, both institutionally and personally for those charged with attendance responsibilities. The competing goals and different perspectives of the various institutional actors-school authorities, child welfare personnel, prosecutors, law enforcement, and juvenile courts - who deal with truancy often lead to deadlock and unseemly shifting of responsibilities. ${ }^{32}$

School authorities, dominated in truancy work by social workers, often tend to view the problem as one of family dysfunction or, in extreme cases, dependency and neglect. ${ }^{33}$ Child welfare authorities look to the schools as the

30. Arthur C. Johnson Jr., Our Schools Make Criminals, 33 J. CRIM. L. \& CRIMINOLOGY 310, 310 (1942). Johnson's article is one of the earliest to explicitly identify the-school-to-prison-pipeline. See also A. Lewis Rhodes \& Albert J. Reiss, Jr., Apathy, Truancy and Delinquency as Adaptations to School Failure, 48 SOC. FORCES 12 (1969) (linking school failure to future “deviancy"); Bruce Balow, Delinquency and School Failure, 25 FED. PROBATION 15 (1961) (drawing connections between delinquent behaviors and school problems). See generally Symposium, School-to-Prison-Pipeline Symposium, 54 N.Y.L. SCH. L. REV. 867 (2010) (elaborating legal challenges to school district policies and practices resulting in the so-called "school-to-prison-pipeline" - a practice that pushes students out of the classroom and into the criminal or juvenile justice systems.).

31. See generally William H. QUINN, FAMILY SOlUTIONS FOR YOUTH AT RISK: APPLICATIONS TO JUVENILE DELINQUENCY, TRUANCY AND BEHAVIOR PROBLEMS (2004)(stressing the importance of family and community contexts in designing interventions for court-involved youth) ; CARLEN ET AL., supra note 2 (rejecting "carrot and stick incentive structure" to improving school attendance and proposing a holistic model of student engagement in their own education).

32. The resort by school systems to truancy prosecution as the "ultimate truancy intervention" contains an ironic element. SMINK \& HEILBRUNN, supra note 8, at 19. In recent years, intervention by courts in the educational process has been criticized by commentators who view law-driven school reform as antidemocratic, fiscally irresponsible, and educationally limiting. See generally, FROM SCHOOLHOUSE TO COURTHOUSE: THE JUdiCIARY'S ROLE IN AMERICAN EDUCATION (Joshua M. Dunn \& Martin R. West eds., 2009); RICHARD ARUM, Judging SCHOOL Discipline: ThE CRISIS OF MORAL AUTHORITY (2003). These commentators should applaud the retreat of juvenile and family courts from truancy prosecutions, yet they have remained silent on this issue. Conversely, other commentators have lamented the retreat of the Supreme Court in recognizing the constitutional rights of students. See Erwin Chemerinsky, The Deconstitutionalization of Education, 36 LOY. U. CHI. L.J. 111 (2004). See also David M. Engstrom, Civil Rights Paradox? Lawyers and Educational Equity, 10 J.L. \& POL'Y 387 (2002).

33. See, e.g., CARLEN ET AL., supra note 2, at $65,94$. 
driving force of the problem. ${ }^{34}$ Without resources or services of their own to address truancy, law enforcement and prosecuting authorities look to the schools, the child welfare system, and the juvenile courts for solutions. ${ }^{35}$ To these authorities, truancy prosecutions serve as early warnings to children and youth who may start down the path of law breaking. Juvenile court judges and personnel also cast a wide net of responsibility for truancy cases and view their purpose as a mixture of treatment, rehabilitation, and punishment. ${ }^{36}$ This issue of colliding institutional competences and capacities is not new in analyzing approaches to tough social problems. But, as always, the issue on the ground is infinitely more complicated, with local factors often dominating theoretical approaches.

Nevertheless, there are certain touchstones that lead to the conclusion that truancy should be decriminalized. First, the incentives for school systems to investigate the educational causes of truancy are thin. Large bureaucracies, even those with personnel who are well-meaning and dedicated, are hesitant to lay blame on themselves. Even when the institutional will exists, the resources, training, and leadership may be lacking. As will be elaborated below, the incentive structure to remediate educational issues for at-risk students may be changing due to the federal No Child Left Behind Act ("NCLB"), 37 a development that holds fragile promise for reducing the number of students deemed truant. By strongly emphasizing test scores, however, NCLB may not be flexible enough to accommodate the needs of chronically absent students for educational interventions and programs that do not fit the rigid metrics of NCLB accountability.

Second, the phenomenon of school exclusion, or push-out, is now welldocumented ${ }^{38}$ Students often make rational decisions to abandon their education because of unnecessarily harsh disciplinary practices, ${ }^{39}$ regimented approaches to gaining academic credits and progress toward graduation, subtle

34. In recent years child welfare systems have come under federal court orders to reduce the number of children in state custody. See, e.g., Kenny A. ex rel. Winn v. Perdue, 454 F. Supp. $2 d 1260$ (N.D. Ga. 2006), aff d, 532 F.3d 1209 (11th Cir. 2008), rev'd and remanded, 130 S. Ct. 1662 (2010), and vacated, 616 F.3d 1230 (11th Cir. 2010) (considering allegations of serious deficiencies in plaintiffs' foster care, including assigning excessive numbers of cases to inadequately trained and poorly supervised caseworkers and failing to develop administrative controls to place children in foster homes that met their specific needs); Settlement Agreement, Brian A. v. Sundquist, No. 3:00-0445 (M.D. Tenn. Jul. 27, 2001) (assessing failures by the Tennessee Department of Children's Services to meet its obligations to children in foster care). This mandate inexorably created a disincentive for child welfare authorities to take into custody children who are solely truant.

35. See, e.g., Begin, supra note 4.

36. Martin \& Snyder, supra note 1 , at 44.

37. 20 U.S.C. $\S \S 6301-6578$ (2006).

38. AdvOCATES FOR CHILDREN, SCHOOL PUSHOUT UPDATE 1 (2008), available at http:// www.advocatesforchildren.org/pubs/pushout_update_2008.pdf ("School push-out happens when students are illegally excluded from school."). See also Davin Rosborough, Left Behind, and then Pushed Out: Charting a Jurisprudential Framework to Remedy Illegal Student Exclusions, 87 WASH. U. L. REV. 663 (2010); Sam Dillon, Study Finds High Rate of Imprisonment Among Dropouts, N.Y. TIMES, Oct. 9, 2009, at 0A (reporting that students who drop out of high school compose a disproportionate number of incarcerated high school age youths).

39. See, e.g., Katayoon Majd \& Patricia Puritz, The Cost of Justice: How Low-Income Youth Continue to Pay the Price of Failing Indigent Defense Systems, 16 GEO. J. ON POVERTY L. \& POL'Y 543 (2009). 
discouragement about a student's prospects of success in school, maintenance of an unwelcoming environment, and court-referrals. ${ }^{40}$ Truancy prosecutions are one manifestation of school exclusion.

Third, school systems possess more resources than the other institutional players in truancy. Schools are uniquely positioned among the actors in truancy to understand root causes and to bring to bear interdisciplinary approaches and services to the student. School systems should understand these approaches from their obligations to serve students eligible for special education, an obligation not imposed on the other truancy actors.

Fourth, by drastically curtailing the ability of school systems to file truancy petitions in court, if not eliminating this course of action, the responsibility for addressing a student's needs will fall squarely on the system best equipped to handle this complicated task. In an article on school "drop-outs," a similar problem, education scholars observed:

The focus on the social, family and personal characteristics [of drop-outs] does not carry any obvious policy implications for shaping school policy and practice. Moreover, if the research on drop-outs continues to focus on the relatively fixed attribute of students the effect of such research may well be to give schools an excuse for their lack of success with the dropout. ${ }^{41}$

Finally, in a seminal article on truancy, two experts in criminal law criticize the use of the juvenile courts as "bludgeons to compel unwilling children to attend school." 42 The authors claim that such compulsion is fundamentally in conflict with the underlying purposes of compulsory education statutes: "It is doubtful whether coerced education will 'prepare citizens to participate effectively and intelligently in our open political system' so as 'to preserve freedom and independence."'t3 A leading book on truancy by education scholars notes that "using the full force of law" to deal with truancy is counterproductive to "treating students as [clients and consumers], and moving to engage students in the process of their own education." 44

\section{THE NONTRANSPARENT LEGAL CONTOURS OF TRUANCY}

Truancy cases implicate a host of potential legal issues. Because truancy cases are filed predominantly in juvenile or family courts, where procedural rules are more relaxed and the presence of defense lawyers is rare, legal issues embedded in truancy cases often fall under the radar. This section will survey the most salient of these issues, several of which are currently being litigated for the first time. The below examples from several class actions help frame the adverse impacts that truancy prosecutions have on students.

40. GUARE \& COOPER, supra note 2, at 2 .

41. Gary G. Wehlage \& Robert A. Rutter, Dropping Out: How Much Do Schools Contribute to the Problem?, 87 TCHRS. C. REC. 374, 376 (1986).

42. Irene M. Rosenberg \& Yale L. Rosenberg, Truancy, School Phobia and Minimal Brain Dysfunction, 61 MiNN. L. REV. 543, 599 (1977).

43. Id. (citing Wisconsin v. Yoder, 406 U.S. 205, 221 (1972)).

44. GUARE \& COOPER, supra note 2, at 79. 
Francisco De Luna, a student in McAllen, Texas, was diagnosed with Attention-Deficit Hyperactivity Disorder in the third grade. ${ }^{45}$ In the sixth grade his school refused to continue administering Francisco's medication, and his focus, grades, and attendance began to suffer. ${ }^{46}$ When Francisco was thirteen, his father died, and his mother was forced to work longer hours to support her family. ${ }^{47}$ Francisco's school attendance suffered, and he was cited numerous times for failing to attend school. ${ }^{48}$ The citations stated that Francisco displayed a "defiant attitude" and "did not want to learn." ${ }^{49}$ Francisco's behavior at school deteriorated, and he was suspended serially from school. ${ }^{50}$ In truancy court, he waived his rights and pled guilty. ${ }^{51} \mathrm{He}$ was fined, and he and his mother were ordered to pay $\$ 257$ to $\$ 383$ per month, including court costs. ${ }^{52}$ The case remained open. ${ }^{53}$ Francisco did not appear at a scheduled court appearance, and, based on his failure to appear and to pay the fines associated with his truancy violations, he was ultimately arrested and jailed for eighteen days. ${ }^{54}$ The complaint alleges that Francisco suffered "psychological damage, humiliation, mental anguish, and emotional injury." 55

Jeremy Bowen was a special education student in Rhode Island. ${ }^{56}$ Schools officials prosecuted Jeremy for truancy after he missed two days of school and was late five days. ${ }^{57}$ Specifically, the officials sought to have Jeremy adjudicated as "wayward."58 Allegedly, the truancy petition was filed because of his difficulties with class and homework, not his absences. ${ }^{59} \mathrm{He}$ and his mother made several appearances in court until the case was dismissed following the intervention of an attorney and the provision of additional services and supports to Jeremy by the school system. ${ }^{60}$ The complaint alleges that Jeremy and his mother experienced stress, anxiety, and humiliation in the course of the proceedings. ${ }^{61}$

45. These facts are derived from the class action complaint filed by the American Civil Liberties Union Foundation of Texas in a constitutional challenge to the incarceration of students for failing to pay fines imposed in truancy prosecutions. Class Action Complaint at 16, De Luna v. Hidalgo County, No. 7:10-cv-00268 (S.D. Tex. Jul. 26, 2010).

46. Id. at $16-17$.

47. Id. at 17 .

48. Id.

49. Id.

50. Id. at 18 .

51. Id. at 19 .

52. Id.

53. Id. at 20 .

54. Id. at 20-24.

55. Id. at 24 .

56. These facts are derived from the class complaint filed by the American Civil Liberties Union in a constitutional challenge to the operation of truancy courts in the state. Class Action Complaint at 36-39, Boyer v. Jeremiah, C.A. No. 2010-1858 (R.I. Mar. 29, 2010).

57. Id. at 37 .

58. Id.

59. Id.

60. Id. at 43-44.

61. Id. at 42 . 


\section{A. The Right to Counsel in Truancy Cases}

While there is limited refined data on the number of students represented by counsel in truancy cases, it is still possible to make a few observations. First, except for the recent litigation in the state of Washington establishing the right to counsel in a child's first truancy filing, ${ }^{, 2}$ the right to counsel does not attach as a constitutional matter in any other state upon the filing of a first truancy petition. Second, the number of reported truancy cases around the country is infinitesimally small compared to the number of petitions filed. ${ }^{63}$ This suggests that very few cases are appealed, which indicates that vigorous advocacy is rare. ${ }^{64}$ Finally, the limited literature on truancy prosecutions strongly suggests that these cases are recursive. In other words, prosecuted students are required to make multiple court appearances to demonstrate compliance with conditions of probation and to show progress in school attendance and performance. The expense of counsel for these hearings is prohibitive for families with limited financial means. 65

Most students who are prosecuted for truancy are from low-income families and cannot afford an attorney. ${ }^{66}$ Yet the potential consequences flowing from a truancy prosecution can be severe. ${ }^{67} \mathrm{~A}$ recent case in the United States Supreme Court underscored the importance of advising defendants of the consequences of a guilty plea. In Padilla $v$. Kentucky, the Court held that a defense counsel's failure to advise his client that a plea of guilty made him subject to automatic deportation violated the defendant's right to effective assistance of counsel. ${ }^{68}$ The principles behind Padilla should apply in truancy prosecutions where students are subject to potential sanctions, such as incarceration and other punitive measures.

The guiding hand of counsel at the first truancy filing can stave off these consequences. ${ }^{69}$ This was the rationale cited by the Washington Court of Appeals in Bellevue School District v. E.S.70 The court used the due process balancing test

62. Bellevue School District v. E.S., 199 P.3d 1010 (Wash. Ct. App. 2009).

63. With upwards of 57,000 truancy petitions filed nationwide, the author's research of reported truancy cases showed only a handful of reported cases from a few states.

64. See generally Federle, supra note 20 (questioning the quality of advocacy in juvenile courts).

65. HeILBRUNN, supra note 9, at 14-16 (estimating that attorneys, if paid on an hourly basis, would receive $\$ 55$ for each hour spent in court and $\$ 45$ for each hour spent out of court).

66. See generally Majd \& Puritz, supra note 36 (discussing the institutional barriers to effective representation that low-income youth face in the juvenile justice system).

67. See generally BYE ET AL., supra note 6 . As noted above, these consequences can include incarceration, fines, involuntary community service, loss of driving privileges, imposition of curfews, mandatory counseling programs, and other sanctions.

68. 130 S.Ct. 1473 (2010).

69. See A.B.A., The Right to COunsel in Status Offense CASES 1 (2010), available at http://new.abanet.org/child/publicdocuments/right_to_counsel_factsheet.pdf (discussing the right of adult status offenders to be advised of their right to counsel and its applicability to juvenile defendants). But see Iowa v. Tovar, 541 U.S. 77, 81 (2004) (holding that the trial court may accept waiver of counsel and a guilty plea if it informs the defendant of the nature of the charges, the right to counsel, and the range of allowable punishments).

70. 199 P.3d 1010 (Wash. Ct. App. 2009). 
found in Mathews v. Eldridge $e^{71}$ to balance the important interests at stake for the student-including the right to a meaningful education-against the risks of an erroneous finding of truancy by the court and the inability of youthful defendants to adequately raise available defenses. The Washington court therefore determined that the Fourteen Amendment required counsel to be appointed at an initial truancy hearing. ${ }^{72}$ Counsel in truancy cases, as in delinquency cases, must exercise heightened sensitivity in their truancy representation to the array of differences-such as disability, language, and class - that often characterize students involved in truancy prosecutions. ${ }^{73}$

\section{B. Guilty Pleas in Truancy Prosecutions}

Given the volume of truancy cases that many juvenile courts handle and the prevailing perception that these cases are not susceptible to formal legal procedures, it is no surprise that the formalities associated with guilty pleas are effectively ignored. The overwhelming majority of students prosecuted for truancy self-represent and pleads guilty. ${ }^{74}$ Many are told only the number of days that they have been absent from school without a meaningful colloquy about potential defenses or justifications for their absences. The lack of formal protections for juveniles pleading guilty led the Kentucky Court of Appeals to hold that the standards of Boykin v. Alabama, ${ }^{75}$ which govern the constitutional minima in the taking of guilty pleas, apply in truancy prosecutions. ${ }^{76}$ Acknowledging the less formal nature of juvenile court proceedings, the court nevertheless insisted that a meaningful plea colloquy is essential in truancy cases. ${ }^{77}$

\section{Justification Issues}

Truancy can be conceived as a series of different narratives specific to each student. Each student has a uniquely personal story of why she or he is chronically absent from school. ${ }^{78}$ Not all of these narratives are recognized in all

71. 424 U.S. 319,335 (1976) (holding that determining the need for pre-deprivation due process hearing requires balancing the private interest being deprive and the risk of erroneous deprivation with the government's burden in providing due process).

72. Bellevue, 199 P.3d at 1011. See Scott v. Illinois, 440 U.S. 367, 373-74 (1979) (holding that no indigent defendant may be sentenced to imprisonment without court-appointed representation at trial); Argersinger v. Hamlin, 407 U.S. 25, 40 (1972) (holding no prison sentence may be imposed unless a defendant was represented by counsel); Hurrell-Haring v. New York, 930 N.E.2d 217, 227 (N.Y. 2010) (holding defendants must receive representation at arraignment in proceedings where counsel is guaranteed (citing Brewer v. Williams, 430 U.S. 387, 399 (1977)).

73. See Tamar R. Birckhead, Culture Clash: The Challenge of Lawyering Across Difference in Juvenile Court, 62 RUTGERS L. REV. 959, 982-86 (2010) (arguing juvenile lawyers should incorporate the principles of the "Five Habits of Cross-Cultural Lawyering" in their practice to promote better relationships between the lawyer and the client).

74. See In re T.T., No. A127275, 2010 Cal. App. Unpub. LEXIS 8561, *2 (Cal. App. 1 Dist. Oct. 28, 2010) (noting that $99.9 \%$ of the students before the court choose not to be represented by an attorney).

75. 395 U.S. 238, 243 (1969) (holding that a defendant must explicitly waive their due process right to a trial before a court can accept their guilty plea).

76. N.K. v. Commonwealth, 324 S.W.3d 438, 441-43 (Ky. Ct. App. 2010).

77. Id.

78. See GUARE \& COOPER, supra note 2, at 17-71 (analyzing the multiple "causes" of truancy.) 
states as legitimate reasons or justifications for absences. Most states count as excused absences reasons such as: personal illness or medical appointments, ${ }^{79}$ illness of an immediate family member, a death in the family, extreme weather conditions, court appearances, recognized religious observances, legal quarantine of the home, and circumstances that, in the discretions of school authorities, are judged to create emergencies over which a student has no control. 80

The circumstances that might justify a student's absences are often much more nuanced than the official lists of excused absences published by school systems. Most prominently, students with unidentified educational disabilities typically involving mental or emotional issues ${ }^{81}$-often are prosecuted for truancy in violation of the Individuals With Disabilities Education Act ("IDEA") 82 or section 504 of the Rehabilitation Act ("section 504"). ${ }^{83}$ The Child Find provisions of IDEA obligate each school system to identify, evaluate, and certify, where appropriate, students within their jurisdiction who are eligible for special education and related services under that statue 84 or protection from discrimination under section 504.85 If a student is suspected of having an educational disability, he or she is protected under the safeguards of the IDEA until a final determination of non-eligibility is made. Until such time, school authorities should be barred from prosecuting students for truancy under the IDEA $^{86}$ since truancy is not a "crime" that can be referred to appropriate authorities for students with disabilities. ${ }^{87}$

There are other justifications that do not make the formal lists. For example, students who are the victims of school-based bullying, harassment, or intimidation cannot be blamed for viewing their school as a hostile environment. ${ }^{88}$ They may not, however, be in a position to articulate their trauma to school authorities; missing school is a likely consequence. Similarly, students

79. These events usually must be documented, which is an often insurmountable problem when a family has difficulty transporting their child to see a doctor. A family without transportation, for example, cannot practically be expected to produce a doctor's note excusing an absence for illness. TENnCARE URgent CARE TRAnSPORTAtion AmENDMENT (Sept. 2008) (on file with author) (requiring Medicaid managed care organizations to provide transportation to doctors' offices within three hours of notification by Medicaid recipient).

80. See, e.g., Truancy Definition, TENN. DEP'T OF EDUC. (Apr. 12, 2010) (on file with author).

81. The wide range of youth mental health issues associated with students who are chronically absent is surveyed IN NixON PEABODY LLP, RESEARCH ON YOUTH MENTAL HEALTH, JuvENILE JusticE, AND PARENTAL ENGAGEMENT FOR THE District Of COlumbia (2010) (on file with author). Students who are gifted are often not served either under the IDEA or equivalent state laws. Yet these students can easily become alienated in their school environment and miss days of school. See Elizabeth A Siemer, Bored Out of Their Minds: The Detrimental Effects of No Child Left Behind on Gifted Children, 30 WASH. U. J. L. \& PUB. POL'Y 539, 546 (2009).

82. 20 U.S.C. $\S \S 1400-1491$ (2006).

83. 29 U.S.C. $\S 794$ (2006).

84. 20 U.S.C. $\S \S 1400-1491$ (2006); 34 C.F.R. §§ 300.1-300.818 (2011).

85. 29 U.S.C. $\$ 794$ (2006); 34 C.F.R. §§ 104.1-104.61 (2011).

86. 20 U.S.C. $\S 1415(\mathrm{k})(6)$ (2006).

87. See Dean Hill Rivkin, Decriminalizing Students with Disabilities, 54 N.Y.L. SCH. L. REV. 909 (2010) (elaborating on the process for referral).

88. See generally RANA SAMPSON, U.S. DeP'T OF Justice, OfFice OF CMTY. ORIENTED POLICING SERVS., BULLYING IN SCHOOLS (2009), available at http:/ / www.cops.usdoj.gov/pdf/e12011405.pdf. 
who are gifted may develop an aversion to attending school. Students who are subject to excessive discipline at school may also be reluctant to return.

A recent study of truancy that surveyed students about their reasons for not attending school propounded an explanation of truancy based on rational choice theory. ${ }^{89}$ Under this theory "students make fairly sophisticated calculations and decisions, weighing the pros and cons of attending school or class, taking risks based on the costs of cutting against the benefits of attending, and thus 'test the system' to see how far they can go." 90 This power to choose by students is denied to them by the compulsory education laws. The solution, the study's authors propose, is to abandon the "get tough" or "law and order" approach to truancy and treat students as the consumers of their own education. ${ }^{91}$ By so doing, the authors urge schools to develop creative approaches to satisfy the needs and wants of their students and present a rich menu of approaches that would reduce truancy rates..$^{92}$

\section{Valid Court Orders and Orders of Probation}

Under the Juvenile Justice and Delinquency Prevention Act of 1974 ("Act"), juvenile judges possess the authority to issue Valid Court Orders ("VCOs") in status offense cases such as truancy prosecutions. ${ }^{93}$ This authority allows judges to impose mandatory conditions on students who plead guilty to truancy and to enforce these conditions with contempt and potential incarceration. Although the right to counsel should attach in a hearing alleging multiple violations of a VCO, the ability of a defendant collaterally to challenge a prior plea or a prior finding of violation when the defendant did not have counsel is precluded. ${ }^{94}$ Additionally, conditions routinely specified in VCOs are unrealistic. ${ }^{95}$ Requiring a student who has been chronically truant to attend school regularly borders on the impossible for many students who have journeyed this far in the truancy process. Other conditions could include prohibitions on being subject to school discipline, mandated passing of courses, submission to drug and alcohol testing, abstention from the unlawful consumption of drugs or alcohol, and others.

The VCO exception is under critical challenge today. There has been abuse of this vehicle to punish youth for status offenses, contrary to the intentions of the Act. ${ }^{96}$ Evidence also suggests that the VCO is used disproportionately against youth of color. ${ }^{97}$ Further, there is no evidence that the imposition of a VCO has a meaningful impact on the behavior of affected youth. To the contrary, the

89. GUARE \& COOPER, supra note 2 , at 13-15.

90. Id. at 13 .

91. Id. at $76-81$.

92. Id. at 73-86.

93. 28 C.F.R. $\S 31.303$ (f)(iii)(3) (2011).

94. See Bellevue School Dist. v. E.S., 199 P.3d 1010, 1012 (Wash. Ct. App. 2009).

95. See, e.g., PAT ARTHUR, NAT'L CTR. FOR YOUTH LAW, THE INCARCERATION Of STATUS OFFENDERS UNDER THE VALID COURT ORDER EXCEPTION TO THE JUVENILE JUSTICE AND DELINQUENCY PREVENTION ACT (2008), available at http://www.youthlaw.org/fileadmin/ncyl/youthlaw/juv_justice/ Homeless_Youth_Presentation_2_.pdf.

96. Id.

97. Id. 
incarceration of status offense youth through VCOs may worsen their behavior by exposing them to other incarcerated youth serving time for more serious offenses and subject them to debilitating psychological harm, especially those youth who suffer from mental health issues. ${ }^{98}$ For these reasons, the National Council of Family and Juvenile Court Judges has urged Congress to repeal the VCO exception in the upcoming reauthorization of the Juvenile Justice and Delinquency Prevention Act. ${ }^{99}$ The United States Department of Justice has also urged repeal of this provision. ${ }^{100}$

\section{E. Educational Neglect}

Educational neglect is a charge brought against a parent for failing to ensure that his or her child is getting an education in accordance with local compulsory education laws. ${ }^{101}$ Truancy or non-compliance with compulsory education laws is dealt with under diverse state schemes, including who is held accountable for a child's truancy. ${ }^{102}$ Educational neglect is a charge that places this accountability squarely on the parents, and in some states these cases must be handled by child welfare agencies. ${ }^{103}$

The issue of educational neglect, however, is often murky due to the numerous parties and interests that are involved. ${ }^{104}$ Communication between the parties often breaks down because educational neglect falls within the jurisdiction of the Department of Health and Welfare, the Department of Education, and with the parents of truant youth. Attention to the child at issue and the reasons for his or her truancy are often lost in the jumble of poorly

98. See generally Peter LeOne \& LOIS WeINBERG, CTR. FOR JUVENILE JustiCE REFORM, AdDrESSING THE UNMET EducAtional NeEdS OF CHILdREN AND YOUTH IN THE JUVENILE Justice AND CHILD WELFARE SYSTEMS (2010), available at http:/ / www.modelsforchange.net/publications/ 260 (discussing the effects of incarceration); Elizabeth Cate, Teach Your Children Well: Proposed Challenges to Inadequacies of Correctional Special Education for Juvenile Inmates, 34 N.Y.U. REV. L. \& Soc. CHANGE 1 (2010).

99. NAT'L COUNCIL OF FAMILy \& JUVEnILE COURT JUdGES, RESOlution REGARDing EFFORTS TO ENSURE AVAILAbILITy OF EVIDENCE-BASEd SERVICES TO MEET THE NEEDS OF STATUS OFFENDERS AND THEIR FAMILIES 1 (2010), available at http://www.ncjfcj.org/images/stories/pdf/ga\%20 evidencebased $\% 20$ svcs\%20resolution.pdf.

100. Letter from Ronald Weich, Assistant Attorney Gen., U.S. Dep't of Justice, to Senator Patrick J. Leahy, Chairman, Comm. on the Judiciary (Apr. 15, 2010), available at http://ojjdp.ncjrs.gov/ enews/10juvjust/DOJViewsLetterS678.pdf.

101. 68 AM. JUR. 2D Schools § 272 (2010). Perversely, in Saez v. City of Springfield, parents unsuccessfully sued their children's school district under 42 U.S.C. § 1983 for educational neglect, claiming that the school district violated their Fourteenth Amendment due process rights by not physically restraining from leaving school during instructional hours. No. 09-2134, 2010 WL 2881512, slip op. (1st Cir. Jul. 22, 2010).

102. MYRIAM L. BAKER ET AL., U.S. DeP'T OF JUSTICE, TRUANCY REDUCTION: KEEPING STUdENTS IN SCHOOL 1 (2001), available at http:/ / www. ncjrs.gov/pdffiles1/ojjdp/188947.pdf.

103. Child Welfare's Back Alley: "Educational Neglect," NAT'L COAL. FOR CHILD PROTECTION REFORM, http:/ /nccpr.blogspot.com/2010/06/child-welfares-back-alley-educational.html (June 21, 2010) [hereinafter NCCPR Child Welfare Blog].

104. See Philip P. Kelly, CTR. FOR SCH. Improvement \& POlicy StUdies, CTR. Of Educ., Boise StATE UniV., EDUCATIONAL NEGLECT \& COMPUlSORY SCHOOLING IN IDAHO: 13,954 REASONS TO TAKE ACTION 1 (2006), available at http:/ / csi.boisestate.edu/pdf/EducationalNeglectLegislativeBrief.pdf. 
delineated responsibilities and duties between the parties. ${ }^{105}$ Many states have statutes that clearly define the role of the parent in compulsory education, thus making it easy to prosecute when all elements of the offense are met. ${ }^{106}$ Other states can prosecute parents under a compulsory education law that uses arguably vague language. ${ }^{107}$ Another problem is that many states can prosecute parents for educational neglect in a number of ways, while often little attention is paid to the school's complicity to a child's truant behavior. ${ }^{108}$

As a result, parents are often faced with a misdemeanor charge or other criminal charge or penalty, or receive formal notice of an investigation by child protective officers. ${ }^{109}$ Child protective services often become overwhelmed by reports of educational neglect that are best addressed by improved communication between parents and the schools. ${ }^{110}$ In fact, "[c]hild protective workers ... receive reports in which the school has made a report to the [state child welfare agency] without first investigating the parent's role in the child's absences," a move made possible by a lack of standard procedure at schools. ${ }^{111}$ Further, following up on these reports strains the limited resources of such agencies, which must also investigate reports of domestic violence, sexual abuse, and neglect of children. ${ }^{112}$

Ironically, schools and agencies often blame parents for truancies while never considering that schools themselves may be better situated to reduce the number of truant students and bear some responsibility for the truancies in the first place. One successful principal of an urban charter school poignantly articulates this lapse in logic, remarking:

If a parent keeps her child out of school for one week, that parent can be charged with educational neglect, a crime punishable by fines and imprisonment in all 50 states. When a school fails to educate 1,000 children, it's called an achievement gap, attestable to poverty, race, neighborhood, etc. ${ }^{113}$

Before schools and other agencies place an often irrebuttable burden on parents to explain why their child is chronically absent from school, there must be a more comprehensive, transparent, and well-defined system for handling truant youth.

105. Id. at 2

106. CHILDREN'S LAW OFFICE, TRUANCY AND EDUCATIONAL NEGLECT 1 (2005), available at http:/ / childlaw.sc.edu/frmPublications/TruancyEducationalNeglect.pdf.

107. See State v. White, 509 N.W.2d 434 (Wis. Ct. App. 1993) (holding that Wisconsin's statute was not unconstitutionally vague).

108. See In re Jamol F. Child, 878 N.Y.S.2d 581, 585-87 (Fam. Ct. 2009). See generally CHILDREN'S LAW OFFICE, supra note 106.

109. See, e.g., BAKER, supra note 5, at 3; 68 AM. JUR. 2D Schools § 271 (2010). See also Alex Berg \& Megan Gibson, Should Parents Be Punished for Teenage Truancy?, HufFINGTON POsT, Jun. 8, 2010, http:/ / www.huffingtonpost.com/alex-berg/should-parents-be-punishe_b_605006.html.

110. JeSSICA GUNDERSON ET AL., VERA INST. OF JUSTICE, RETHINKING EDUCATIONAL NEGLECT FOR TEENAGERS: NEW STRATEGIES FOR NEW YORK STATE 10-16 (2009).

111. Id. at 8 .

112. NCCPR Child Welfare Blog, supra note 103.

113. Steve Perry, Getting Rid of Bad Teachers: The Unions 'Plant' Mentality, N.Y. TIMES: ROOM FOR DEBATE BLOG (March 3, 2010, 6:00 PM), http://roomfordebate.blogs.nytimes.com/2010/ 02/24/getting-rid-of-bad-teachers/. 


\section{THE RIGHT TO EDUCATION}

Since the seminal case of Brown v. Board of Education, ${ }^{114}$ which articulated the centrality of equal educational opportunity under the United States Constitution, the right to education has been developed in cases in a variety of educational contexts. Despite profound language in several United States Supreme Court cases that emphasize the core democratic values served by universal education in our country, 115 litigation over the right to education has been consigned to the state courts. In San Antonio School District v. Rodriguez, the United States Supreme Court rejected the claim that education was a fundamental right under the Fourteenth Amendment to the United States Constitution. ${ }^{116}$ Rodriguez was largely responsible for the shift in the litigation strategies of educational reformers. ${ }^{117}$ In many respects, this was a favorable development, one that produced long-term gains in educational opportunity and achievement from what was perceived as a profound civil rights loss. ${ }^{118}$

These gains were rooted in state constitutional provisions that more explicitly recognized the benefits of a quality education and the overriding duty of the state to provide such a system of schools. ${ }^{119}$ In the wave of cases following Rodriguez, state high courts consistently invalidated inequitable school financing schemes. ${ }^{120}$ Despite the many variations in these decisions, school children were the beneficiaries of this litigation regarding state constitutions.

A related wave of litigation followed the school finance cases and was often integrally intertwined with them. These cases became known as the school adequacy cases. ${ }^{121}$ Resting on state constitutional provisions and statutes, the school adequacy cases considered the inadequate provision of education to students. ${ }^{122}$ Consequently, school systems were ordered to provide a sound basic education to students. ${ }^{123}$

A recent development similarly reinforces a broad state constitutional right of access to education for students who are suspended or expelled for violating school rules. Using a state equal protection standard of intermediate scrutiny, the

114. 347 U.S. 483 (1954).

115. See, e.g., Plyer v. Doe, 457 U.S. 202, 221-23 (1982); Dean Hill Rivkin, Legal Advocacy and Education Reform: Litigating School Exclusion, 75 TENN. L. REV. 265 (2008).

116. 411 U.S. 1 (1973).

117. See generally, Michael Heise, The Story of San Antonio Indep. Sch. Dist. v. Rodriguez: School Finance, Local Control, and Constitutional Limits, in EDUCATION LAW STORIES (Michael A. Olivas \& Ronna G. Schneider eds., 2007).

118. See generally JULES LOBEL, SUCCESS WiTHOUt ViCTORY: LOST LEGAL BATTLES AND THE LONG ROAD TO JUSTICE IN AMERICA (2003) (recounting how "lost" legal campaigns often produce soughtafter reforms in other forums).

119. John DINAN, School Finance Litigation: The Third Wave Recedes, in From SCHOOLHOUSE TO COURTHOUSE: THE JUdiciarY'S ROLE In AMERICAN EduCATION 96 (Joshua M. Dunn \& Martin R. West eds., 2009).

120. Id

121. See, e.g., William S. Koski \& Rob Reich, When "Adequate" Isn't: The Retreat from Equity in Educational Law and Policy and Why It Matters, 56 EMORY L.J. 545 (2006).

122. Gershon M. Ratner, A New Legal Duty for Urban Public Schools: Effective Education in Basic Skills, 63 TEX. L. REV. 777, 818-23 (1985).

123. Id. 
North Carolina Supreme Court held in King v. Beaufort County Board of Education that school administrators must articulate an important or significant reason for denying a student access to alternative education. ${ }^{124}$ This right shifts the burden to school systems to justify exclusion of offending students from continuing educational opportunities.

Several commentators have argued courts should explicitly recognize a "right to learn."125 These commentators emphasize that compulsory education laws impose deep restraints on students' liberty interests, resulting in a duty to ensure that each student receives a tailored educational program. ${ }^{126}$ This claim is anchored in substantive due process. ${ }^{127}$

The lynchpin case supporting a right to learn is Youngberg $v$. Romeo. ${ }^{128}$ In Youngberg, the United States Supreme Court found that involuntarily committed persons with mental retardation "enjoy[ed] constitutionally protected interests in conditions of reasonable care and safety, reasonably nonrestrictive confinement conditions, and such training as may be required by these interests."129 Employing a balancing test, which weighed the "individual's interest in liberty against the State's asserted reasons for restraining individual liberty,"130 the Court found that the state must provide these individuals "minimally adequate training." 131 Concurring, Justice Blackmun stated that individuals in state mental hospitals were constitutionally entitled to a right to "habilitation," or training that would prevent a person from losing "pre-existing self-care skills" while confined. ${ }^{132}$ The decision accorded deference to the judgment of professionals in determining the contours of this right to training. ${ }^{133}$

One commentator ${ }^{134}$ linked the right to training found in Youngberg to the professional standards mandated by the federal No Child Left Behind Act of 2001 ("NCLB"). ${ }^{135}$ If students are in schools that do not meet minimum requirements under NCLB, students should have a legitimate substantive due process claim to an adequate education, or a "right to learn."136 In the truancy context, state rules that mandate individualized educational services to truant students also provide professional benchmarks for asserting a constitutional claim to a minimally effective educational program. A leading lawyer in school adequacy litigation campaigns has urged that the right to "meaningful

124. 704 S.E.2d 259, 265-267 (N.C. 2010).

125. See, e.g., Daniel S. Greenspahn, A Constitutional Right To Learn: The Uncertain Allure of Making a Federal Case Out of Education, 59 S.C. L. REV. 755 (2008); Note, supra note 24.

126. Greenspahn, supra note 125, at 774 (citing Penelope A. Preovolos, Rodriguez Revisited: Federalism, Meaningful Access, and the Right to Adequate Education, 20 SANTA CLARA L. REV. 75, 101 (1980)).

127. Greenspahn, supra note 125 , at $773-75$.

128. 457 U.S. 307 (1982).

129. Id. at 324 .

130. Id. at 320 .

131. Id. at 322 .

132. Id. at 327 (Blackmun, J., concurring).

133. Id. at 328 (Blackmun, J., concurring).

134. Greenspahn, supra note 125 , at 755.

135. 20 U.S.C. §§ 6301-6578 (2006).

136. Greenspahn, supra note 125, at 755. See also Note, supra note 24. 
educational opportunity," requires that "children ... be provided a range of programs and services that respond directly to their educational needs False"137 Still another analyst has urged that, in the context of excluding students from education under zero tolerance policies, schools have an affirmative duty to address the underlying causes of improper behavior by students. ${ }^{138}$

Additionally, the United States Constitution requires a searching scrutiny of the justifications for prosecuting students for truancy and visiting on them the sanctions that often flow from truancy cases. The United States Supreme Court in Graham v. Florida used the Eight Amendment to invalidate a sentence of life without parole for a juvenile who committed armed burglary and related crimes. 139 The lower court's sentence rested on weak penological justifications. ${ }^{140}$ Canvassing the four goals of penal sanctions-retribution, deterrence, incapacitation, and rehabilitation-the Court held that none of these goals justified a sentence of life without parole. ${ }^{141}$ The Court also noted the special challenges faced by juvenile defense counsel, including the youths' "[d]ifficulty in weighing long-term consequences; a corresponding impulsiveness; and reluctance to trust defense counsel ...."142 These dynamics are compounded in the truancy context, where counsel is rarely present and where the right of the child to "accuracy, dignity, and participation"143 - the "core" of due process protections for juveniles - is observed only in the breach.

Truancy prosecutions fall into a netherworld of legal proceedings. As a status offense, truancy is not technically a crime. Yet the consequences of truancy prosecutions can equal the sanctions imposed on juvenile offenders who commit delinquency offenses, which are deemed crimes. The penal justifications that are subliminally asserted to justify truancy prosecutions are as unpersuasive as those proffered in Graham v. Florida. Retribution ${ }^{144}$ and incapacitation are not apt goals for prosecuting students for truancy. ${ }^{145}$ Deterrence and rehabilitation, on the

137. Michael A. Rebell, Poverty, "Meaningful" Educational Opportunity, and the Necessary Role of the Courts, 85 N.C. L. Rev. 1467, 1514 (2007).

138. Emily Bloomenthal, Inadequate Discipline: Challenging Zero Tolerance Policies as Violating State Constitution Education Clauses, N.Y.U. Rev. L. SOC. CHANGE (forthcoming Mar. 2011), available at: http:/ / ssrn.com/abstract $=1573256$.

139. 130 S.Ct. 2011 (2010).

140. Id. at 2028-30.

141. Id.

142. Id. at 2032.

143. Emily Buss, The Missed Opportunity in Gault, 70 U. CHI. L. REv. 39, 47 (2003).

144. A form of retribution is often meted out by judges in truancy cases through tough talk and explicit threats of escalated sanctions. The negative consequences that such hard-line discourse can have on inherently fragile children and youth is frequently not part of the judicial calculus. Similarly, zero tolerance and other punitive disciplinary policies have been shown to generate perverse consequences for students. See, e.g., American Psychological Ass'n Zero Tolerance Task Force, Are Zero Tolerance Policies Effective in the Schools? An Evidentiary Review and Recommendations, 63 AM. PsYCHOLOGIST 852 (2008) (arguing retributive truancy prosecutions cannot withstand rational scrutiny).

145. Although students who are incarcerated for truancy may receive education services in juvenile detention, where being absent would be near impossible, no one justifies truancy prosecutions for this reason. Indeed, incarceration, even short-term, has potentially high adverse effects on children and youth: "According to a large body of national research, the detention environment, by itself, can exacerbate and/or cause mental health problems, substance abuse, stress- 
other hand, cannot be summarily rejected as rationales for truancy prosecutions. The flaw in citing these two goals to justify truancy prosecutions, however, is that there is no valid data to support either the deterrent or rehabilitative effects of truancy prosecutions. ${ }^{146}$ Before visiting on youthful defendants the collateral consequences that often flow from truancy prosecutions, there should be more solid evidence that such prosecutions rationally advance the goals of deterrence or rehabilitation and are narrowly tailored to achieve these ends. Anecdotal evidence of the effectiveness of deterrence and rehabilitation in the truancy context should not suffice for the same reasons Graham rejected the punishment levied in that case. When dealing with youth, punishments must be carefully crafted to the needs and developmental levels of youthful defendants.

The goals of deterrence and rehabilitation presumably are advanced in truancy reduction programs. Such programs, however, frequently do not precede the initiation of court proceedings, and there are no good grounds for resorting to the courts in these cases. The fact that a random student or two may be "cured" of his or her truancy through court intervention is an insufficient reason to justify the current system of undifferentiated prosecutions. As demonstrated by the recursive nature of these prosecutions and their overwhelming numbers, prosecution of truant students only faintly deters this conduct. Additionally, the overarching goal of rehabilitation cannot be achieved in the overwhelming majority of juvenile courts that do not possess the resources to provide robust educational and social services programs for prosecuted students. ${ }^{147}$

When woven together, the strands of a right to education merge into an enforceable claim for students who are subjected to prosecution for truancy. This claim is rooted in the education provisions of state constitutions, federal and state substantive and procedural due process clauses, and state and federal statutes 148 that require school systems to provide effective, heightened educational services to children and youth. This right can also be justified by the enervated penological justifications for sanctioning students for truancy, especially through incarceration and other intrusive restraints on liberty and deprivations of property. The demonstrable failure of these punitive approaches to remedying the multiple causes of truancy leaves the current system bereft of

related illnesses and learning difficulties and send young people back to their families and communities with increased anger, frustration or depression." ROBIN L. DAHLBERG, AM. CIV. LIBERTIES UNION, LOCKING Up OUR CHILDREN: THE SECURE DETENTION OF MASSACHUSETTS YOUTH AFTER ARRAIGNMENT AND BEFORE ADJUDICATION 25 (2008), available at http://aclum.org/sites/all/ files/education/locking_up_our_children_web.pdf.

146. See Jessica Gunderson, Vera Inst. of Justice, Getting TeEnagers Back To School: RETHINKING NEW YORK STATE'S RESPONSE TO CHRONIC ABSENCE 7 (2010), available at http:/ / www.vera.org/ download?file=3062/Ed-neglect-summary-revised-v5-copyedit.pdf.

147. An effective educational intervention is multi-layered and depends on the quality of implementation. The intervention must be implemented in a variety of difference settings. See Russell J. Skiba, Suzanne E. Eckes \& Kevin Brown, African American Disproportionality in School Discipline: The Divide Between Best Evidence and Legal Remedy, 54 N.Y.L. SCH. L. ReV. 1071, 1075 (2010).

148. See The No Child Left Behind Act of 2001, 20 U.S.C. §§ 6301-6578 (2006). Title I states: “The purpose of this subchapter is to ensure that all children have a fair, equal, and significant opportunity to obtain a high-quality education and reach, at a minimum, proficiency on challenging State academic achievement standards and state academic assessments." 20 U.S.C. § 6301. 
reasonable justification. This reality should strengthen arguments for the recognition of a right to education that must be exhausted before resort is made to the current, bankrupt system.

\section{THE Right TO THE Right EdUCATION}

\section{A. The Special Education Model}

Students who are eligible for special education services under the federal Individuals With Disabilities Education Act (IDEA) are entitled to a Free Appropriate Public Education (FAPE) that is embodied in an Individualized Education Program (IEP) designed to meet the unique educational needs of each eligible student. ${ }^{149}$ Through the participation of a student's parents, experts, and school personnel, an IEP is formulated to ensure that each eligible student makes genuine educational progress. ${ }^{150}$ The student is also entitled to a range of related services, including psychological counseling, social work services, transportation, parent counseling and training and other interventions. ${ }^{151}$ Eligible students are also entitled to transition services designed to aid them in their transition from high school to productive postgraduate opportunities. ${ }^{152}$ For those students who meet only the eligibility criteria of section 504, an antidiscrimination statute, a similar plan of accommodations must be created. ${ }^{153}$ For students whose behavior in schools transgresses rules and prevailing norms, IDEA and 504 require that a functional behavior assessment (FBA) be performed and a behavior intervention plan (BIP) be developed. ${ }^{154}$ It is beyond the scope of this piece to elaborate on the detailed requirements that govern IEPs or section 504 plans or the array of educational practices and social supports that are contained in these programs. However, for purposes of fashioning a right to the "right" education for students prosecuted for truancy, the special education model demonstrates the expertise that resides in school systems for meeting the needs of students with complex education challenges. By law, this model is premised on scientifically based best practices. ${ }^{155}$ Similar models, though not as widely documented, exist in the truancy literature. ${ }^{156}$ The right to such an

149. The IDEA IEP requirements are codified at 20 U.S.C. § 1415(e) (2006).

150. Id.

151. 34 C.F.R § 300.34 (2010).

152. 34 C.F.R $\S 300.43$ (2010).

153. See 34 C.F.R. § 104.33(b)(1)(i), (b)(2) (2010). See also Mark C. Weber, A New Look at Section 504 and the ADA in Special Education Cases, 16 TEX. J. C.L. \& C.R. 1 (2010).

154. 29 U.S.C. § 794 (2006). See also Perry A. Zirkel, Commentary, An Updated Comparison of the IDEA and Section 504/ADA, 216 EDUC. L. REP. 1 (2007) (discussing the differences between an IEP under the IDEA and a section 504 accommodation plan).

155. Individuals with Disabilities Education Act (IDEA), 20 U.S.C. 1401(c)(5)(E) (2006).

156. See GUARE \& COOPER, supra note 2, at 73-86 (proposing models that meaningfully engage students and parents in the educational enterprise); REID, supra note 6, at 194-218 (detailing models for improving school attendance); Russell J. Skiba, Suzanne E. Eckes \& Kevin Brown, African American Disproportionality in School Discipline: The Divide Between Best Evidence and Legal Remedy, 54 N.Y.L. SCH. L. REV. 1071, 1089-1100 (2010) (arguing that judicial deference to school officials' decisions in disciplinary matters is misplaced in light of evidence that such deference disproportionately affects African-American students); NAT'L CTR. FOR SCHOOL ENGAGEMENT, TRUANCY PREVENTION IN ACTION: BEST PRACTICES AND MODEL TRUANCY PROGRAMS (2005), available at 
individualized program in the truancy context can be asserted as a defense in a truancy prosecution or requested as a remedy in a systemic challenge to local truancy prosecutions schemes, where effective interventions are not provided prior to the institution of a truancy prosecution. ${ }^{157}$

This approach has been advocated by several commentators who claim that each student, regardless whether a student meets the rigorous eligibility criteria of IDEA, should receive a program modeled on a special education IEP. 158 The argument for a universal IEP resonates in progressive educational communities and in legal circles where disability scholars seek to loosen distinctions between disabled and nondisabled students and extend the concept of equality to all students. ${ }^{159}$ Regardless of the ultimate merits of this broad-gauged approach, students who are threatened with prosecution for chronic truancy often possess the at-risk characteristics that animated the creation of the IDEA. Students who are truant form a class akin to the students with disabilities who were excluded form school in the days before the IDEA and were the beneficiaries of the entitlements Congress conscientiously enacted. These students were effectively excluded from schools without meaningful programs for their inclusion. The right to the right education for students who are truant is a natural evolution of a right that some argue is a "human right."160

\section{B. NCLB And Beyond}

NCLB has introduced unprecedented nationwide standards of accountability into public school systems that have long neglected the need for the individualization of education for all students. ${ }^{161}$ Under NCLB, the failure of

http://www.schoolengagement.org/TruancypreventionRegistry/Admin/Resources/Resources/TruancyPreventio ninActionBestPracticesandModelTruancyPrograms-ExecutiveSummary.pdf.

157. See Boyer v. Jeremiah, No. 2010-1858 (R.I. Super. Ct. Mar. 29,2010) (rejecting motions to dismiss in a class action complaint filed against numerous school systems and municipalities for their treatment of truant students). See also supra note 15 (discussing De Luna v. Hidalgo County, 7:10-cv00268 (S.D. Tex. Jul 26, 2010)).

158. See, e.g., Deborah Gordon Klehr, Addressing the Unintended Consequences of No Child Left Behind and Zero Tolerance: Better Strategies for Safe Schools and Successful Students, 16 GEO. J. ON POVERTY L. \& POL'Y 585 (2009); Stephen A. Rosenbaum, Full SP [ ]ED Ahead: Expanding the IDEA Idea to Let All Students Ride the Same Bus, 4 STAN. J. C.R. \& C.L. 373, 384-88 (2008); Judith D. Singer, Should Special Education Merge With regular Education?, 2 EDUC. POL'Y 409 (1988).

159. See, e.g., Martha Minow, Making All the Difference: InClusion, ExClusion, AND AMERICAN LAW (1990).

160. See, e.g., Kimberly Jenkins Robinson, The Case for a Collaborative Enforcement Model for a Federal Right to Education, 40 U.C. DAVIS L. REV. 1653, 1689- 1726 (2007) (applying international human rights enforcement mechanisms to define and enforce a right to education); ELIZABETH SULLIVAN \& ElizABETH KEENEY, NAT'L ECON. \& SOC. RightS INITIATIVE, TEACHERS TAlK: SCHOOL CUlture, SAFETY AND HUMAN RIGHTS 6 (2008), available at http:/ / www.nesri.org/Teachers_Talk.pdf ("Human rights standards specifically encourage the use of preventive and proactive approaches that protect access to education and build social and behavioral skills needed for positive learning environment"). See also A.B.A. SEC. ON LitigATION, CHILD. RIGHTS LiTIG. COMMIT., RAISING OUR HANDS: CREATING A NATIONAL STRATEGY FOR CHILDREN'S RIGHT TO EDUCATION AND COUNSEL iv-v (2009).

161. Mark Burgreen, Being Neighborly in Title 20: Using the IDEA to Lend a Helping Hand to NCLB, 43 ColuM. J.L. \& SOC. PROBS. 51 (2009) ("The major difference between NCLB and past standards- 
a small cohort of students to progress and graduate can lead to the imposition of wide-ranging remedial measures for failing schools. These measures include "school choice,"162 "supplemental educational services,"163 and compelled investments in school staff and facilities. NCLB is operating in an environment where competition from charter schools and new forms of private education is pushing the envelope of pupil individualization in public school systems. These developments do not necessarily mean that there will be unqualified progress in serving profoundly at-risk students. If charter schools, for example, are allowed to exercise unconstrained discretion to push-out students who do not conform to their rigorous programs, public schools will be faced with an even greater concentration of students who need heroic efforts to engage them and their families in real educational opportunities.

For purposes of crafting individualized programs for students who are chronically truant, the NCLB-induced climate of educational innovation is guardedly promising. Such innovations as School-Wide Positive Behavioral Interventions and Supports, ${ }^{164}$ programs of restorative justice, ${ }^{165}$ the offering of educational programs designed to meet students interests in nontraditional subjects that have often been subsumed by the neglected category of vocational education, the provision of cutting-edge compensatory educational services, ${ }^{166}$ and other approaches to enhancing student engagement all hold the potential to serve students who are truant and failing to complete high school. ${ }^{167}$ The

based legislation is that NCLB serves as an unprecedented federal expansion into educational policy, boasting rigorous accountability provisions.").

162. See 20 U.S.C. $\S 6316(\mathrm{~b})(1)(\mathrm{E})(\mathrm{i})$ (2006) ("In the case of a school identified for school improvement under this paragraph, the local educational agency shall . . provide all students enrolled in the school with the option to transfer to another public school served by the local educational agency, which may include a public charter school, that has not been identified for school improvement under this paragraph, unless such an option is prohibited by State law.").

163. See 20 U.S.C. $§ 6316($ b)(5)(B) (2006) ("In the case of any school served under this part that fails to make adequate yearly progress . . . the local educational agency serving such school . . . shall make supplemental educational services available consistent with subsection (e)(1) of this section ....").

164. See R.H. Homer, G. Sugai, A.W. Todd \& T. Lewis-Palmer, School-Wide Positive Behavior Support: An Alternative Approach to Discipline in Schools, in INDIVIDUALIZED SUPPORTS FOR STUDENTS WITH PROBlem BeHAVIORS: Designing Positive BeHAVIOR Plans 359-90 (L. Bambara \& L. Kern eds., 2005) (demonstrating integrated, school-wide approaches to school discipline, rather than focusing on individual misconduct).

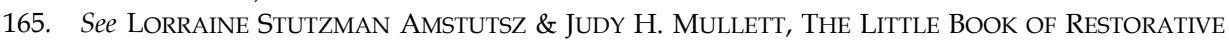
DisCIPLINE FOR SCHOOLS: TEACHING RESPONSIBILITY; CREATING CARING CLIMATES (2005) (providing a restorative justice approach for remedying school misconduct).

166. Amy P. Meek, School Discipline "As Part of the Teaching Process": Alternative and Compensatory Education Required by the State's Interest in Keeping Children in School, 28 YALE L. \& POL'Y REV. 155, 17280 (2009) (comparing cases decided under state constitutions that have been interpreted to extend a right to an alternative education for suspended or expelled students). The individualized educational services for youth in correctional facilities provide a model for the educational services proposed in this article for students who are habitually truant and subject to prosecution. For a description of these services see Elizabeth Cate, Teach Your Children Well: Proposed Challenges to Inadequacies of Correctional Special Education for Juvenile Inmates, 34 N.Y.U. REV. L. \& SOC. CHANGE 1, 28-36 (2010).

167. See AMERICAN PSYCHOLOGICAL ASS'N ZERO TOLERANCE TASK FORCE, supra note 144, at 857859 (advocating for a more therapeutic approach to school discipline); Lucille Eber et al., Wraparound and Positive Behavioral Interventions and Supports in the Schools, $10 \mathrm{~J}$. EMOTIONAL \& BEHAV. DISORDERS 171 (2002) (proposing robust mental health-based interventions for students with problematic school behaviors). 
opportunities and pitfalls that these programs present are formidable, but the climate of experimentation that has been stimulated by NCLB is bound to continue. For students who are truant because traditional educational programs are unsuited to their development, needs, and interests; there is cautious hope on the horizon that all students will be understood and served appropriately. ${ }^{168}$

\section{CONCLUSION}

This article urges the creation of judicially-imposed rights or legislativelycreated schemes that will decriminalize truancy. ${ }^{169}$ The collateral consequences of maintaining the current system of truancy prosecutions of students outweigh any demonstrated value to deploying the courts in this social and educational morass. ${ }^{170}$ The gradual trend toward individualization in K-12 education is the right course to ensure that each student receives an adequate education. These methods of individualization should draw on the evidence-based best practices demonstrated in the special education laws. Some of the most promising school reform efforts promote the engagement of all students in the educational environment through supports such as small learning communities, the creation of a system of advocates for families and students, and instructional changes that are tailored to the strengths and interests of each student. ${ }^{171}$ Juvenile and family courts, law enforcement, and prosecutors have minimal resources and training to deal with the educational and therapeutic underpinnings of truancy. They should be relieved of these responsibilities. The resources that now are devoted to truancy prosecutions - and enhanced funding - should be placed in the hands of competent school systems, affiliated social services, and community-based agencies whose missions explicitly encompass the provision of the right education for each student.

168. Fringe movements, such as "unschooling," are receiving marginally more attention in today's dynamic educational climate. See Frequently Asked Questions, UNSCHOOLING.COM, http:/ / www.unschooling.com/library/faq/index.shtml (last visited Apr. 3, 2011) (advocating a freechoice approach to youth learning). See also Jacques Steinberg, Plan B: Skip College, N.Y. TIMES, May 14, 2010, at WK.1 (reporting an increase in recent calls for more intensive, short-term vocational training as an alternative to a college degree).

169. See A.B.A., COMM'N ON YOUTH AT RISK AND COMM'N ON HOMELESSNESS AND POVERTY, REPORT TO THE HOUSE OF DELEGATES 1-4 (2008), available at http://www.abanet.org/ youthatrisk/reports.pdf (urging policymakers and attorneys to protect the rights of children to a high quality education). See also Franklin E. Zimring, The Common Thread: Diversion in Juvenile Justice, 88 CAL. L. REV. 2477, 2493-94 (2000) (identifying the diversionary function of the juvenile court as a singular achievement in reducing the incarceration of youth).

170. See Jill Carter \& Alan Leschied, Maintaining Mental Health and Youth Justice-Involved in Mainstream Education: Implications for Ontario's New Mandatory Requirement for School Attendance, 19 EDUC. \& L.J. 169, 174 (2010) ("Research has demonstrated that the use of the courts alone to reduce school absences is ineffective, especially in cases of chronic truancy or for youth who have already been involved in the justice system.").

171. See Edward L. Deci, Large-Scale School Reform As Viewed from The Self-Determination Theory Perspective, 7 THEORY \& RES. IN EDUC. 244 (2009) (proposing "small learning communities" and "a family and student advocate" system under a psychology-based approach to school reform). See also Robert Balfanz, Liza Herzog \& Douglas J. MacIver, Preventing Student Disengagement and Keeping Students on the Graduation Path in Urban Middle-Grades Schools: Early Identification and Effective Interventions, 42 EDUC. PSYCHOLOGIST 223 (2007) (implementing screening mechanisms and tailored interventions to respond to student behavioral needs). 